\title{
Evaluation of Efficiency of Academic Activities in the Universities of European Higher Education Area and in Ukraine
}

\author{
Olha Palamarchuk \\ Institute of Higher Education of the National Academy of Educational Sciences \\ of Ukraine, Kyiv, Ukraine \\ o.palamarchuk@ihed.org.ua
}

\begin{abstract}
The urgent task of today is ensuring the quality of the educational process, adherence to academic integrity, and evaluation of the efficiency of academic activities of universities. Foreign publications mainly offer one of the most widely used concepts, called BSC - a balanced scorecard for measuring performance and Key Performance Indicators (KPIs). National researchers consider the problem of implementation KPI indicators in the activities of universities in achieving their strategic goals, solving the management problem of evaluating the effectiveness of the university management and structural units of the administration. The development of indicators of the efficiency of academic activities of the university should be individual. There were used such methods as analysis, systematization, and generalization for defining the state of the researched problem in foreign and national literature, comparative analyses for finding indicators of academic activities of the universities in the international and national ratings, defining selected indicators at the top10 universities in Ukraine and method of generalization for writing conclusions and recommendations. The selected indicators should correspond to the mission of each university and at the same time include a common set of indicators to assess its effectiveness. Based on the analysis of the literature, international and national rankings, we propose the system of indicators for the evaluation of the effectiveness of academic activities of the university and give suggestions and recommendations at the national, sectoral, and institutional levels. We recommend considering the indicators of academic activity before developing/writing methodological recommendations on higher education standards, provisions on advanced training of academic staff, Framework of Excellence for academic staff. Universities should be able to go through a smooth, continuous process of change that ensures the effectiveness of the university's research activities and provides resources for teaching and learning. We offer universities to conduct self-assessment and internal ranking of the effectiveness of academic activities.
\end{abstract}

Keywords: Evaluation of efficiency, Academic activity, System of indicators, University, Key performance indicators, Effectiveness, Rankings

\section{Background and status}

The modern paradigm of education requires a rethinking of the mission of universities and their role in the social, economic, and knowledge-intensive development of states. The urgent

Article history:

Received (February 27, 2021), Review Result (March 30, 2021), Accepted (May 5, 2021) 
task of today is the implementation of institutional autonomy of higher education institutions, ensuring the quality of the educational process, modernization of educational programs, professionalism, and competitiveness of research and teaching staff increasing the prestige of teaching professions and scientists, adherence to academic integrity, commercialization of universities and also evaluation of the efficiency of academic activities of universities.

The issue of evaluating the effectiveness of higher education institutions is relevant in the European Higher Education Area (EHEA), as evidenced by analytical reports of the European University Association (EUA) [2][3][4][5][7][11][13] and others. However, there are certain indicators of evaluation of the effectiveness of the academic activities in the universities of Europe that are presented and evaluated, higher education institutions in Ukraine lack such a system of indicators. Evaluation of the efficiency of academic activities in the universities of Ukraine, elaboration of certain indicators needs to be improved based on European experience and need further research and enhancement of evaluation system at the national, sectoral, and institutional level.

The development of a system of indicators of the effectiveness of academic activities of the universities of Ukraine was carried out by the following methodology:

(a) Analysis of EUA metrics, particularly in the area of education.

(b) Analysis of indicators of Teaching Excellence Framework.

(c) Defining the main indicators of academic activity in international rankings: Times Higher Education (THE) World University Rankings; Academic Ranking of World Universities (ARWU); QS World University Rankings, "THE Impact Rankings", "The Europe Teaching Ranking".

(d) Analysis of national metrics and indicators: rating "Top 200" Osvita.ua; formulas for the distribution of expenditures under the article "Training of academic staff and ensuring the operation of their bases of practice" for 2020

(e) Literature review of the foreign and national researchers.

(f) Selection of the indicators based on the analyses above.

(g) Analyses of the top-10 universities of Ukraine (by the admission of students) on the evaluation of the effectiveness of academic activities by using selected indicators (based on the rector's annual reports).

(h) Writing conclusions and recommendations.

To fulfill methodology and conduct research, there were used such methods as analysis, systematization, and generalization for defining the state of the researched problem in foreign and national literature, comparative analyses for finding indicators of academic activities of the universities in the international and national ratings, defining selected indicators at the top-10 universities in Ukraine and method of generalization for writing conclusions and recommendations at national, sectorial and institutional level.

\section{Problem}

The main research is based on fundamental developments in pedagogy, philosophy of education, management of education, and educational process, in particular on humanistic pedagogy, effective methodology of the educational process, anthropological pedagogy, internationalization, and globalization of higher education. The formation of a humanistic 
future is possible not only based on a clear idea of the global problems of the world, but also of such an understanding of the progress that would be oriented towards the scale and criteria of true human values [18].

The report of the European Association of Universities T. Estermann, V. Kupriyanova "Efficiency, Effectiveness and Value for Money at Universities", 2019 examines the effectiveness of activities at the systemic and institutional levels, efficiency in academic issues (research, teaching, and learning) and effectiveness in strategic management. The report offers key recommendation messages to increase the efficiency of universities and the metrics of complementary components of university autonomy.

The indicators of academic activity of universities in the report include:

(a) Rationalization of the academic offer.

(b) Joint study program.

(c) Learning analytics.

(d) Technology-enhanced learning.

(e) Coordination of study portfolio.

(f) Coordination of student flows.

(g) Sharing of teaching space.

(h) Joint application services, student recruitment, and mobility.

(i) Sharing or exchange of teaching staff [3].

We fully share the authors' view that efficiency is the collective responsibility of all higher education stakeholders. Effective and efficient universities and frameworks can only be achieved through ongoing dialogue and joint action by politicians, universities, and their networks.

The report by T. Estermann, V. Kupriyanova "Insight from Ireland and other countries", 2018 analyzes the development of higher education in Ireland and its formation to achieve the effectiveness of universities. Considerable attention is paid by the authors to academic autonomy and the development of improving teaching and learning. In this regard, the National Forum for Teaching and Learning was held in Ireland to discuss the certification of teaching skills, the development of digital resources in teaching, networking among colleagues and like-minded people, creating space for communication and exchange of views, and engage students into the process of improving teaching and learning [4].

Irish higher education institutions are actively working together to increase educational efficiency and effectiveness. This is crucial in light of significant changes in both student enrollment and funding. In line with national priorities for access to higher education, the sector has made a series of recent successful initiatives, such as the introduction of central applications and admission processes for student access, a national student engagement survey, and the overall improvement of teaching and learning. Practices through the systematic exchange of best practices and joint support schemes.

To achieve the effectiveness of universities, attention is focused on the following components of academic activities of the university:

(a) improving teaching and learning;

(b) involvement of students [4]. 
Thus, in the report for our research we are interested in the priority area of work on improving teaching and learning, the creation of the National Forum of Teaching and Learning, which brings together key online teaching and research resources. Impressive are the results of the forum, which developed the first topics for improving learning and teaching in Ireland, set routes for certified development of targeted learning skills, create specialized digital resources to transform teaching, create a network for communication, consultation, and dissemination, and mobilize and engage students to improve teaching and learning.

Teaching Excellence Framework [14] arises high interest in our research because it is based on six key indicators for assessing university excellence, three of which are taken from the results of the annual National Student Survey (NSS). These indicators reflect the student's vision of the quality of teaching, assessment, and academic support received. The fourth indicator of teaching excellence is related to the level of student withdrawal, and the fifth and sixth are related to graduates, namely the level of satisfaction with teaching and learning and the level of their employment in the future.

Quantitative indicators:

(a) Teaching on my course.

(b) Assessment and feedback.

(c) Academic support.

(d) Non-continuation.

(e) Employment / further study.

(f) Highly skilled employment or further study.

Qualitative indicators:

(a) Teaching quality.

Learning environment:

(a) Student outcomes and Learning Gain [14].

For our research of the academic performance of universities, the employment rate of graduates after graduation is crucial.

The effectiveness of academic activities of universities is studied by the tools that include quantitative and qualitative indicators. These indicators can be obtained from the selfassessment, rectors' reports, external independent analysis of the institution's activities, etc.

\section{Cause analysis}

Foreign publications mainly offer one of the most widely used concepts, called BSC - a balanced scorecard for measuring performance and Key Performance Indicators (KPIs). M. Marques and N. Tasic say "The role of the system of performance indicators may be different, depending on the purpose for which it is designed. Four main roles of the system of indicators are identified: evaluation, monitoring, planning, and dialogue". Similarly, the five main roles of performance indicator systems are defined: 1. Monitoring 2. Evaluations 3. Dialogue 4. Rationalization 5. Allocation of resources. Also identified three purposes for which you can use a system of indicators: 
(a) to inform the population about the state of the system;

(b) monitoring of policies, strategies, or plans implemented;

(c) management of the higher education system and higher education institutions in general [6][8].

National researchers such as S. Sereda, N. Hvorostiana, A. Garaschenko also use key performance indicators to assess the effectiveness of universities. National researchers consider the problem of implementation KPI indicators in the activities of universities in achieving their strategic goals, solving the management problem of evaluating the effectiveness of the university management and structural units of the administration $[5][7][13]$.

One of the ways to measure the effectiveness of academic activities of universities is university rankings. Let's move directly to the indicators of academic activity, presented in international and national rankings.

"Performance measurement systems have some general principles and approaches, although they are guided by different objectives, methodologies, and criteria. More commercial systems (THE - Times Higher Education Rankings, Shanghai Academic Ranking - ARWU), usually consider the availability of information as the main criteria for selecting indicators" [16]. Some authors consider several criteria when developing a system of performance indicators, such as relevance of indicators for different users, multidimensionality, measurement, resistance to manipulation, validity, reliability, comparability, availability of information for calculating indicators, etc. [1][16].

The ranking of world universities QS contains indicators that can be attributed to those that assess the quality of teaching and learning. This is, in particular, the academic reputation of the university, which weighs $40 \%$ of the rating. The indicator that the compilers of the rating declare as assessing the quality of teaching is the ratio of the number of teachers and students. The weight of this indicator is $20 \%$ of the rating [12].

Leading the world on sustainable development. Delivering the UN Sustainable Development Goals for health, equality, and sustainability.

The University of Manchester is ranked as the world's top university for impact towards the United Nations' Sustainable Development Goals (SDGs) in 2021 THE Impact Rankings.

The quality and scale of our impact against the UN's Sustainable Development Goals (SDGs) have been ranked first in the world in the Times Higher Education University Impact Rankings in 2021.

The 17 SDGs are the world's call to action on the most pressing challenges and opportunities facing humanity.

As one of the world's leading research institutions and the UK's only university to have social responsibility as a core goal, The University of Manchester is playing a leading role in tackling the SDGs in four ways - through our research, learning, and students, public engagement activities and responsible campus operations. 
Table 1. The ratio of indicators of academic activity of universities in international and national rankings, 2019

\begin{tabular}{|c|c|c|c|c|c|c|}
\hline Indicators & Shanghai & QS & Times & Teaching & Top-200 & Formula \\
\hline Staff to student ratio & & + & + & + & & \\
\hline Academic reputation & & + & + & + & & \\
\hline Assessment of teaching and learning & & & + & + & + & \\
\hline $\begin{array}{l}\text { Number of university graduates who } \\
\text { received the Nobel or Fields Prize }\end{array}$ & + & & & & & \\
\hline $\begin{array}{c}\text { A number of teachers who have a Nobel } \\
\text { or Fields Prize. }\end{array}$ & + & & & & & \\
\hline $\begin{array}{l}\text { The ratio of doctoral students to } \\
\text { bachelors }\end{array}$ & & & + & & & \\
\hline $\begin{array}{l}\text { The ratio of awarded doctoral degrees to } \\
\text { the number of academic staff. }\end{array}$ & & & + & & & \\
\hline Gender balance of academic staff & & & & + & & \\
\hline Gender balance of students & & & & + & & \\
\hline The proportion of international students & & & & + & & \\
\hline Erasmus+ mobility. & & & & + & & \\
\hline Student engagement & & & & + & & \\
\hline $\begin{array}{l}\text { Student interaction; } \\
\text { Student recommendation; } \\
\text { Labor market links. }\end{array}$ & & & & + & & \\
\hline $\begin{array}{c}\text { The number of graduates who completed } \\
\text { the training program compared to the } \\
\text { number of entrants }\end{array}$ & & & & + & & \\
\hline $\begin{array}{c}\text { Assessment by students of the applied } \\
\text { value of the acquired knowledge for } \\
\text { further work }\end{array}$ & & & & + & & \\
\hline $\begin{array}{l}\text { Assessment of the quality of scientific } \\
\text { and pedagogical potential }\end{array}$ & & & & & + & \\
\hline Employability of the graduates & & & & + & & + \\
\hline
\end{tabular}

Therefore, we see that indicator such as the ratio of teachers and students, the academic reputation of the university, and the assessment of the quality of teaching and learning are the same for international rankings. Also common to The Europe Teaching Rankings (The Europe Teaching Ranking, 2019) and for the Formula is the employability of the graduates. There is no indicator of admission to the university in international and national rankings.

The development of indicators of the effectiveness of academic activities of the university should be individual. The selected indicators should correspond to the mission of each university and at the same time include a common set of indicators to assess its effectiveness. Based on the analysis of international and national rankings, we propose to take as a basis the indicators of the effectiveness of academic activities of the university in The Europe Teaching Rankings, which in our opinion most widely presents indicators of academic activities and propose the author's vision of the indicators [15].

The indicators of efficiency of academic activity of university are the following:

(a) The ratio of the number of teachers and students;

(b) Scientific and pedagogical staff involved in professional development activities (number of teachers who received certificates of professional development);

(c) Admission of entrants (annual ranking of universities by number of entrants);

(d) Employment of graduates (satisfaction of graduates with the acquired knowledge, satisfaction of employers with the received specialists); 
(e) Involvement of external experts in the teaching process (percentage or share of international teachers, involvement of employers and other stakeholders in the educational process);

(f) Mobility of teachers and students (number of completed internships and exchange of international experience of teachers and students);

(g) Competitiveness of the university (place in international rankings and ability to compete with leading world-class universities);

(h) Assessment of the reputation of the university (academic reputation is determined by the presence of a higher education institution in international rankings or top 10 in the national ranking "Top 200", the quality of educational services);

(i) Evaluation of teaching and learning (determined by surveying students, rating teachers) [10].

The results of the evaluation of some indicators are presented in [Table 2].

Table 2. Indicators for evaluating the effectiveness of higher education institutions in Ukraine

\begin{tabular}{|c|c|c|c|c|c|c|c|c|c|c|}
\hline $\begin{array}{l}\text { University } \\
\text { indicators }\end{array}$ & 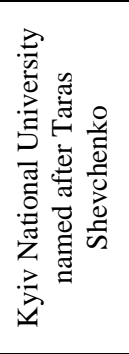 & 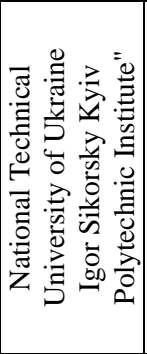 & 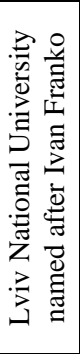 & 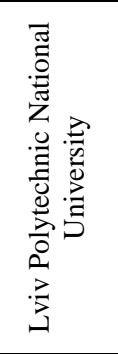 & 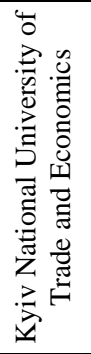 & 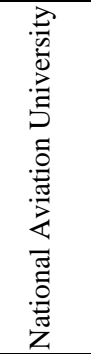 & 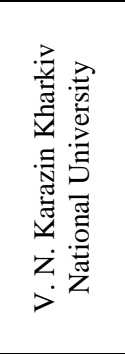 & 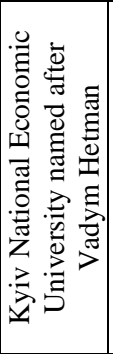 & 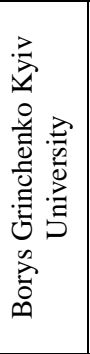 & 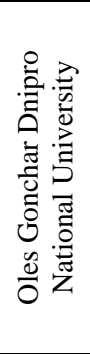 \\
\hline \multicolumn{11}{|c|}{ Academic activities } \\
\hline $\begin{array}{l}\text { Professional } \\
\text { development } \\
\text { of academic } \\
\text { staff }\end{array}$ & 377 & 506 & 347 & 630 & $\begin{array}{l}\text { No } \\
\text { data }\end{array}$ & 424 & No data & 245 & $\begin{array}{l}\text { No } \\
\text { data }\end{array}$ & $\begin{array}{l}\text { No } \\
\text { data }\end{array}$ \\
\hline $\begin{array}{l}\text { Employment } \\
\text { of graduates }\end{array}$ & $\begin{array}{l}\text { IT fest, } \\
\text { soft skills }\end{array}$ & $96 \%$ & $\begin{array}{l}\text { No } \\
\text { data }\end{array}$ & $\begin{array}{c}\text { Fair of } \\
\text { workpla } \\
\text { ces, } \\
\text { StartUP } \\
\text { School }\end{array}$ & $\begin{array}{l}\text { No } \\
\text { data }\end{array}$ & $81 \%$ & No data & $\begin{array}{l}\text { No } \\
\text { data }\end{array}$ & 42 & $\begin{array}{l}\text { No } \\
\text { data }\end{array}$ \\
\hline $\begin{array}{l}\text { Share of } \\
\text { foreign } \\
\text { students }\end{array}$ & $\begin{array}{c}26746 \\
\text { total } \\
\text { (foreign } \\
\text { students- } \\
1675 \text { ) }\end{array}$ & No data & $\begin{array}{l}\text { No } \\
\text { data }\end{array}$ & No data & $\begin{array}{l}\text { No } \\
\text { data }\end{array}$ & $\begin{array}{l}\text { No } \\
\text { data }\end{array}$ & 4066 & 89 & $\begin{array}{l}\text { No } \\
\text { data }\end{array}$ & $\begin{array}{l}\text { No } \\
\text { data }\end{array}$ \\
\hline Mobility & $\begin{array}{c}1829 \\
\text { people }\end{array}$ & No data & 50 & No data & $\begin{array}{l}\text { No } \\
\text { data }\end{array}$ & $\begin{array}{c}21 \\
\text { особа }\end{array}$ & $\begin{array}{c}662 \\
\text { особи }\end{array}$ & $\begin{array}{l}\text { Анг. } \\
\text { викл. }\end{array}$ & $\begin{array}{l}\text { No } \\
\text { data }\end{array}$ & $\begin{array}{c}10 \\
\text { mobili } \\
\text { ty } \\
\text { projec } \\
\text { ts } \\
\end{array}$ \\
\hline $\begin{array}{l}\text { External } \\
\text { experts }\end{array}$ & $\begin{array}{c}22 \\
\text { teachers } \\
\text { from } \\
\text { other } \\
\text { countries }\end{array}$ & No data & 48 & $\begin{array}{l}\text { Coopera } \\
\text { tion } \\
\text { with } \\
\text { enterpri } \\
\text { ses }\end{array}$ & $\begin{array}{l}\text { Coop } \\
\text { eratio } \\
n \text { with } \\
\text { stakeh } \\
\text { olders }\end{array}$ & $\begin{array}{l}\text { No } \\
\text { data }\end{array}$ & $\begin{array}{l}\text { Cooperat } \\
\text { ion with } \\
\text { the } \\
\text { academy } \\
\text { of } \\
\text { sciences }\end{array}$ & $\begin{array}{l}\text { No } \\
\text { data }\end{array}$ & $\begin{array}{l}\text { No } \\
\text { data }\end{array}$ & $\begin{array}{l}\text { No } \\
\text { data }\end{array}$ \\
\hline
\end{tabular}


Thus, the analysis of indicators of evaluation of the academic activity of higher education institutions of Ukraine showed the following:

According to the indicator "Professional development of academic staff", which is measured by the number of scientific and pedagogical staff who improved their skills, the largest values $(630,506,377)$ were received by NU "Lviv Polytechnic", NTUU "Kyiv Polytechnic Institute named after Igor Sikorsky" and Kyiv National University named after Taras Shevchenko. Of the analyzed universities, the Kyiv National Economic University named after Vadym Hetman is at the least important (245).

According to the indicator "Employment of graduates", which is measured as a percentage of the total number of students who graduated from university, the highest values $(96 \%, 81 \%)$ were received by NTUU "Kyiv Polytechnic Institute named after Igor Sikorsky" and the National Aviation University.

According to the indicator "Share of foreign students", the largest value of the number of students $(4066,1675)$ received Kharkiv National University named after VN Karazin and Kyiv National University named after Taras Shevchenko, the lowest value of the indicator, we cannot say, because of very few known data on universities.

According to the "Mobility" indicator, the largest value of the number of people (1829, 662) was received by the Taras Shevchenko National University of Kyiv and the VN Karazin Kharkiv National University, of the analyzed universities the National Aviation University has the lowest value (21).

Lviv National University named after Ivan Franko (48 people) and Kyiv National University named after Taras Shevchenko (22 people) are in the lead in terms of "Involvement of external experts in educational activities". There is no data on other universities.

\section{Countermeasures and suggestions}

Given the above problems and the analysis of existing problems, allowed us to formulate the following conclusions and suggestions:

\subsection{At the national level}

Based on the above analysis, we recommend developing a comprehensive national rating of the effectiveness of higher education institutions by organizational, academic, research, financial/economic type.

Improve the methodology for calculating domestic ratings of higher education institutions in terms of introducing indicators for assessing academic activities, as the national academic rating of higher education institutions of Ukraine "Top-200 Ukraine 2020", developed by international standards, does not contain performance indicators.

Consider the indicators of academic activity before developing/writing methodological recommendations on higher education standards, provisions on advanced training of academic staff, Framework of Excellence for academic staff.

Consider the indicators of academic activity in the proposals for the introduction of freelance and quality monitoring of KPIs - rectors, vice-rectors, heads of structure, subdivision. (to assess the effectiveness of management and academic activities (in terms of management of academic activities), the criteria for the quality of educational activities of the Free Economic Zone for the distribution of public funding [9]. 


\subsection{At the sectoral level}

Universities should be able to go through a smooth, continuous process of change that ensures the effectiveness of the university's research activities and provides resources for teaching and learning. This requires rethinking the idea of change from decision-making to perspective, which perceives change as a new reality and builds an institutional culture based on change.

\subsection{At the institutional level}

We offer universities to conduct self-assessment and internal ranking of the effectiveness of academic activities. We recommend using certain indicators, particularly:

(a) The ratio of the number of teachers and students;

(b) Scientific and pedagogical staff involved in professional development activities (number of teachers who received certificates of professional development);

(c) Admission of entrants (annual ranking of universities by the number of entrants);

(d) Employment of graduates (satisfaction of graduates with the acquired knowledge, satisfaction of employers with the received specialists);

(e) Involvement of external experts in the teaching process (percentage or share of international teachers, involvement of employers and other stakeholders in the educational process);

(f) Mobility of teachers and students (number of completed internships and exchange of international experience of teachers and students);

(g) University competitiveness (place in international rankings and ability to compete with leading world-class universities);

(h) Assessment of the university's reputation (academic reputation is determined by the presence of a higher education institution in international rankings or top 10 in the domestic ranking "Top 200", the quality of educational services);

(i) Assessment of teaching and learning (determined by surveying students, rating teachers).

\section{Acknowledgment}

This paper was sponsored by the National Academy of Educational Sciences of Ukraine by the results of competitive selection for 2020 applied scientific research for supporting young scientists working (studying) in the subordinate institutions of the NAES of Ukraine.

\section{References}

[1] Academic Ranking of World Universities. (2021) http://www.shanghairanking.com.

[2] T. Estermann and V. Kupriyanova, "Efficiency, effectiveness, and value for money: Insights from the UK and other countries," (2018) https://eua.eu/resources/publications/320:efficiency,-effectiveness-and-value-formoney-insights-from-the-uk-and-other-countries-a-ustream-report.html

[3] T. Estermann and V. Kupriyanova, "Efficiency, leadership, and governance: Closing the gap between strategy and execution," USTREAM Report.

https://eua.eu/downloads/publications/final\%20ustream\%20report\%202018.pdf

(2019) 
Evaluation of Efficiency of Academic Activities in the Universities of European Higher Education Area and in Ukraine

[4] T. Estermann, V. Kupriyanova, and M. Casey, "Efficiency, effectiveness, and value for money: Insights from Ireland and other countries," USTREAM Report, (2018), https://eua.eu/resources/publications/756:efficiency,-effectiveness-and-value-for-money-insights-fromireland-and-other-countries.html

[5] G. Sereda, "Experience of universities in the field of implementation of kpi-indicators to achieve strategic goals," (2018) http://jeou.donnu.edu.ua/article/view/6578

[6] M. Marques, "Key performance indicators in Portuguese public universities," (2017) https://www.aabri.com/manuscripts/09240.pdf

[7] N. Hvorostiana and A. Garacshchenko, "Theoretical and methodological fundamentals of the appointment of the effectiveness of the diagnostic of the great primary mortgage," (2012), https://ideas.repec.org/a/scn/032455/15918742.html

[8] N. Tasić, M. Delić, R. Maksimović, B. Lalić, and M. Ćukušić, "Selecting key performance indicators in universities - Academic perspective, (2017), https://www.iim.ftn.uns.ac.rs/is17/papers/95.pdf

[9] O. Palamarchuk, The role of academic staff in university governance (comparative analyses of Ukrainian and other EHEA documents). "Education pedagogy: Problems and prospects for development in the context of reform," Editors: Sławomir Śliwa, Olga Tsybulko. Monograph. Opole: The Academy of Management and Administration in Opole, pp.133-145, (2020), https://www.wszia.opole.pl/wpcontent/uploads/2020/09/2020_education_pedagogy_problems_and_prospects_for_devevelopment_in_contex t_of_reform.pdf

[10] O. Palamarchuk, "Influence of academic staff on the indicators of academic activity of the university. Innovative and information technologies in educational processes," Monograph, Publishing House of University of Technology, Katowice, (2020), pp.32-40, http://repository.vsau.org/getfile.php/25512.pdf

[11] O. Palamarchuk and I. Vlasova, "Evaluation of the efficiency of higher education institution's activities in Ukraine," Periodyk Naukowy Akademii Polonijnej, Częstochowa, s.188, vol.42, no.5, pp.126-134, (2020)

[12] E. B. Pruvot and T. Estermann, "University autonomy in Europe III: The scorecard," (2017) https://eua.eu/downloads/publications/university\%20autonomy\%20in\%20europe\%20iii\%20the\%20scorecard $\% 202017 . p d f$

[13] QS World University Rankings (2021) https://www.topuniversities.com/university-rankings/worlduniversity-rankings/2021

[14] S. Kurbatov, "Universutetski reytungu ta problema ocinku jakosti vukladannia i navchannia," (2018)

[15] Teaching Excellence Framework: Year two additional guidance (2014)

[16] The Europe Teaching Rankings: Methodology, (2019), https://www.timeshighereducation.com/worlduniversity-rankings/Europe-teaching-rankings-2019-methodology

[17] Times Higher Education World University Rankings, (2021), https://www.timeshighereducation.com/worlduniversity-rankings/2021/world-ranking\#

[18] V. Zinchenko, "Humanistic values and enlightenment strategies of global society in the potential of the sustainable development of democracy," American Research Journal of Humanities and Social Sciences, vol.4, no.1, pp.1-13, (2018), DOI: 10.21694/2378-7031.18016 


\section{Authors}

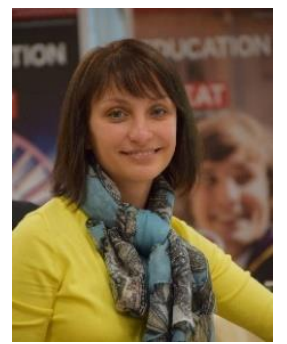

\section{Olha Palamarchuk}

Ph.D. in Educational Sciences, Senior Researcher, Department of Quality Assurance of Higher Education, Institute of Higher Education of the National Academy of Educational Sciences of Ukraine. 
Evaluation of Efficiency of Academic Activities in the Universities of European Higher Education Area and in Ukraine

This page is empty by intention. 